\title{
The role of technological pedagogical content knowledge and social cognitive variables in teachers' technology integration behaviors
}

\author{
Cemal Hakan Dikmen \\ Department of Computer Technologies, Afyon Kocatepe University, Afyonkarahisar, Turkey \\ ORCID: 0000-0002-3708-9091
}

\author{
Veysel Demirer * \\ Department of Educational Sciences, Süleyman Demirel University, Isparta, Turkey \\ ORCID: 0000-0002-3264-9424
}

Article history

Received:

30.04.2021

Received in revised form: 05.07.2021

Accepted:

29.10.2021

Key words:

Technological pedagogical content knowledge,

Social cognitive variables, Teachers' technology integration behaviors
The Technological Pedagogical Content Knowledge (TPACK) framework provides a theoretical perspective of showing whether a teacher can effectively design and conduct technology-enhanced instruction. In addition, social cognitive variables like self-efficacy, outcome expectations, interest and intentions play a vital role in whether teachers choose to integrate technology into their instructional practices. Therefore, this study aimed to investigate the relationships between TPACK dimensions and these social cognitive variables to understand teachers' behaviors in technology integration. For this purpose, a hypothetical model was designed and tested through structural equation modeling to investigate the relationships among these variables. The research sample consisted of 850 teachers from Turkey. The study findings demonstrate that especially teachers' technological knowledge (TK), technological content knowledge (TCK), technological pedagogical knowledge (TPK), and TPACK-core (different interactions of CK and PK with TK) together with their self-efficacy, outcome expectations, and interest have impacts on their intentions to use educational technologies. In this context, teachers with a high level of technological pedagogical content knowledge are more interested in educational technologies, their expectations regarding the outcomes of using instructional technologies increase and they develop behavioral intentions of using educational technologies; as a result, they see/evaluate themselves as more qualified in technology integration. Consequently, the study results are expected to contribute to a better understanding of teachers' behaviors and beliefs toward technology integration in education.

\section{Introduction}

Teacher qualifications, competencies, and experiences play an important role in the planning and implementation of educational activities in classrooms (Demir \& Bozkurt, 2011), and the way teachers use technology has the potential to innovate in education (Carr,

\footnotetext{
* Correspondency: veyseldemirer@gmail.com
} 
Jonassen, Litzinger, \& Marra, 1998; Karatas, Tunc, Yilmaz, \& Karaci, 2017; Koehler \& Mishra, 2005). In this regard, many studies demonstrate the importance of teachers' technology adoption (Raygan, \& Moradkhani, 2020). Shulman (1986, 1987) states that teachers' competencies should involve content knowledge, pedagogical knowledge, pedagogical content knowledge, curriculum knowledge, knowledge of learners' characteristics, educational context knowledge, educational outcomes, objectives, values, and philosophical and historical foundations. Koehler and Mishra (2005) integrated technological knowledge into Shulman's (1986, 1987) pedagogical content knowledge (PCK) and conceptualized the framework of technological pedagogical content knowledge (TPACK). The TPACK framework is shown in Figure 1.

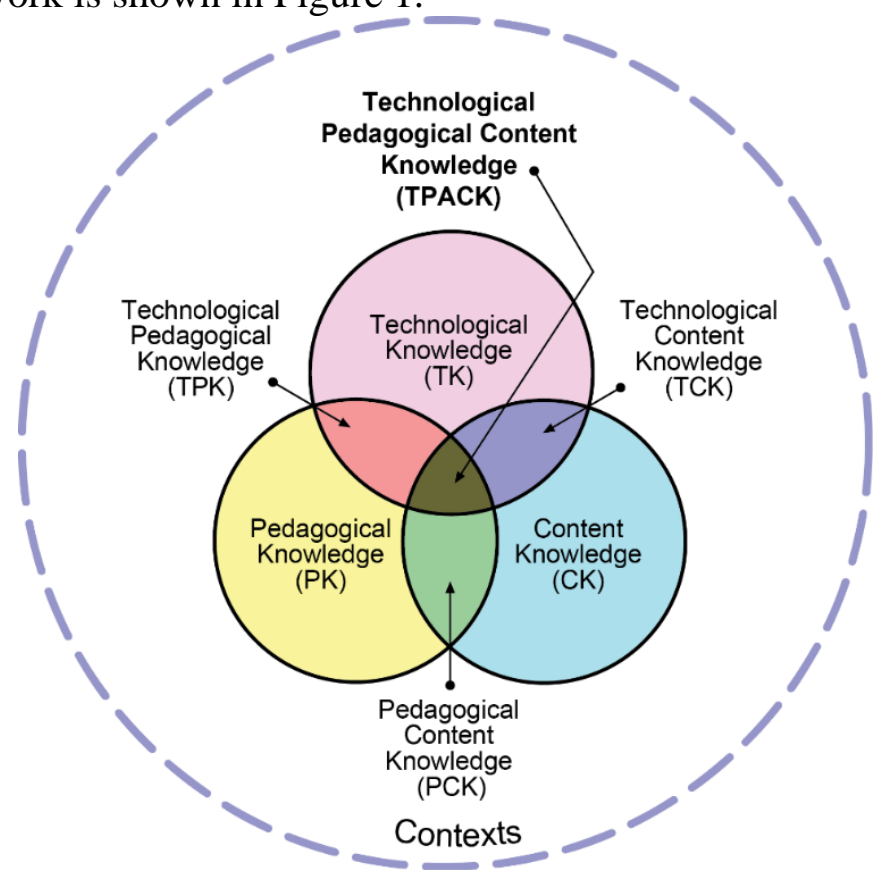

Figure 1. Technological pedagogical content knowledge (Reproduced by permission of the publisher, (C) 2012 by tpack.org)

As with Shulman's $(1986,1987)$ theory of pedagogical content knowledge (PCK), the TPACK framework expresses content knowledge (CK) and pedagogical knowledge (PK) as primary areas of teacher knowledge. Mishra and Koehler (2006) state that CK is information about what is learned or taught about the subject area. PK describes the structure, organization, management, and teaching strategies about how to teach a particular subject area (Wetzel, Foulger, \& Williams, 2008). PCK is used by teachers in subjects that they regularly teach in lessons; it contains information on the presentation of ideas, drawings, examples, explanations and demonstrations. In addition, PCK also requires understanding what makes it difficult or easy to learn in a particular subject area (Shulman, 1986). By extending the PCK model to include technological knowledge (TK) as a third main area of knowledge, Mishra and Koehler's (2006) TPACK framework demonstrates three additional interactions among these knowledge areas: technological content knowledge (TCK; which is combination of technological knowledge, and content knowledge); technological pedagogical knowledge (TPK; which is combination of technological knowledge, and pedagogical knowledge); and technological pedagogical content knowledge (TPACK-core; which is combination of technological knowledge, content knowledge, and pedagogical knowledge). TCK is the knowledge of applying emerging technologies to represent specific subject-matter knowledge, but independent from pedagogical purpose (Saudelli \& Ciampa, 2016). It 
provides information to teachers on the subjects such as providing the transformation of the subject with technological tools, presenting the subject with the designs appropriate to the student qualifications. TPK is the knowledge of applying emerging technologies in pedagogy of all subject domains rather than being restrictively aimed at specific content knowledge (Saudelli \& Ciampa, 2016). In this respect, TPK explains the unique pedagogical approaches developed by the teachers according to the different dynamics of the teaching environment and the degree of intelligibility of the subject (Kereluik, Mishra, \& Koehler, 2011; Koehler \& Mishra, 2009). TPACK-core is the knowledge of applying emerging technologies to support specific pedagogical strategies or goals in the classroom as well as to enhance students' learning in specific subject-matter knowledge (Saudelli \& Ciampa, 2016). TPACK framework is vital for creating and maintaining effective and innovative classroom environments through recommending the integration of technology, pedagogy, and content knowledge (Sen, 2020). For quality teaching, teachers need to develop themselves about the complex interactions between technology, pedagogy, and content knowledge (Alemdag, Cevikbas, \& Baran, 2020; Kereluik et al., 2011).

Since teachers have an important role in the implementation of technology in classrooms, they need to know how to use digital technologies to create better learning environments that promote students' active construction of knowledge (Niess, 2011; Roussinos, \& Jimoyiannis, 2019). Teachers' owning higher degrees of technology literacy, high TPACK levels and positive attitudes contribute significantly to higher technology integration (Raygan, \& Moradkhani, 2020). Therefore, TPACK framework helps understand the knowledge that teachers must adopt for effective technology integration in education (Baran, Chuang, \& Thompson, 2011; Mishra \& Koehler, 2006). It is particularly important to understand the process of development and interactions among these knowledge areas, and how lack of knowledge in one domain can negatively impact an overall technology integration effort (Saudelli \& Ciampa, 2016). In addition to TPACK, studies are investigating the relationships between different variables related to the technology integration in education. Much of these studies are based on the Social-Cognitive Theory (Bandura, 1986) and they show that cognitive or affective responses of individuals affect their behaviors towards using educational technology (Sahin, 2008; Smith, 2002; Wang, Ertmer, \& Newby, 2004). These studies show that teachers' self-efficacy beliefs regarding technology have an influence on their technology integration (Compeau \& Higgins, 1995; Holden \& Rada, 2011; Morales, Knezek, \& Christensen, 2011; Paraskeva, Bouta, \& Papagianni, 2008; Teo, 2009; Watson, 2006). In addition, Niederhauser and Perkmen (2008) emphasized that social cognitive factors like self-efficacy, outcome expectations, and interest play a vital role in whether teachers choose to integrate technology into their instructional practices. As an application of the Social-Cognitive Theory, the Social-Cognitive Career Theory argues that self-efficacy and expectations shape interests and affect intentions, and intentions give rise to successful behaviors in line with goals (Lent, Brown, \& Hackett, 1994, 2002; Lent, Ireland, Penn, Morris, \& Sappington, 2017). Self-efficacy expresses the beliefs about abilities that an individual has in order to realize an action (Bandura, 1986; Bong \& Skaalvik, 2003; Skaalvik \& Skaalvik, 2017). Outcome expectations show the expectations about the results of an action (Shealy et al., 2015). Interest demonstrates whether the individual likes or dislikes something, and it also influences the intentions or decisions to achieve a behavior (Sahin, 2008). In this context, Sahin (2008) examined the effect of instructors' self-efficacy, outcome expectations, and interest in educational technology on their intentions to use the technology. According to his study, technology integration self-efficacy influences instructors' intentions to use educational technologies indirectly, through its impact on instructional technology outcome expectations and interest in educational technologies. According to Albion (2001), social 
cognitive variables such as self-efficacy tend to be mediators for many other external and social factors in terms of technology integration. Based on such a rationale, this study aimed to investigate the relationships between TPACK dimensions and these social cognitive variables to understand teachers' behaviors in technology integration. TPACK significantly predicts teachers' use of technology at school: teachers' beliefs about how to use technology to support content-specific pedagogical strategies influence the way their integrate technology in their teaching activities (Fanni, 2014). Nathan's (2009) research on pre-service teachers' TPACK and technology integration self-efficacy shows that there is a moderate, and positive relationship between these variables. In addition, some studies show that TPACK is positively related to technology integration self-efficacy (Abbitt, 2011; Karatas, 2014; Raygan, \& Moradkhani, 2020; Semiz, \& Ince, 2012; Stewart, Antonenko, Robinson, \& Mwavita, 2013) and instructional technology outcome expectations (Semiz \& Ince, 2012; Stewart et al., 2013). Also, Spazak (2013) suggests that TPACK and high technology self-efficacy are important indicators in ensuring efficient technology integration. In fact, the related literature investigates the relationships between TPACK and different social cognitive variables such as technology integration self-efficacy separately. In the current study, it is aimed to show the relationships between these variables with the effect of TPACK in a holistic manner. Consequently, it is thought that teachers' TPACK dimensions affects their technology integration self-efficacy (TISE), instructional technology outcome expectations (ITOE), interest in educational technologies (IET), and intentions to use educational technologies (IUET). These interactions might affect teachers' technology integration behaviors. Therefore, a hypothetical model was designed and tested through structural equation modeling to investigate the relationships among these variables (Figure 2). The research hypotheses are given below.

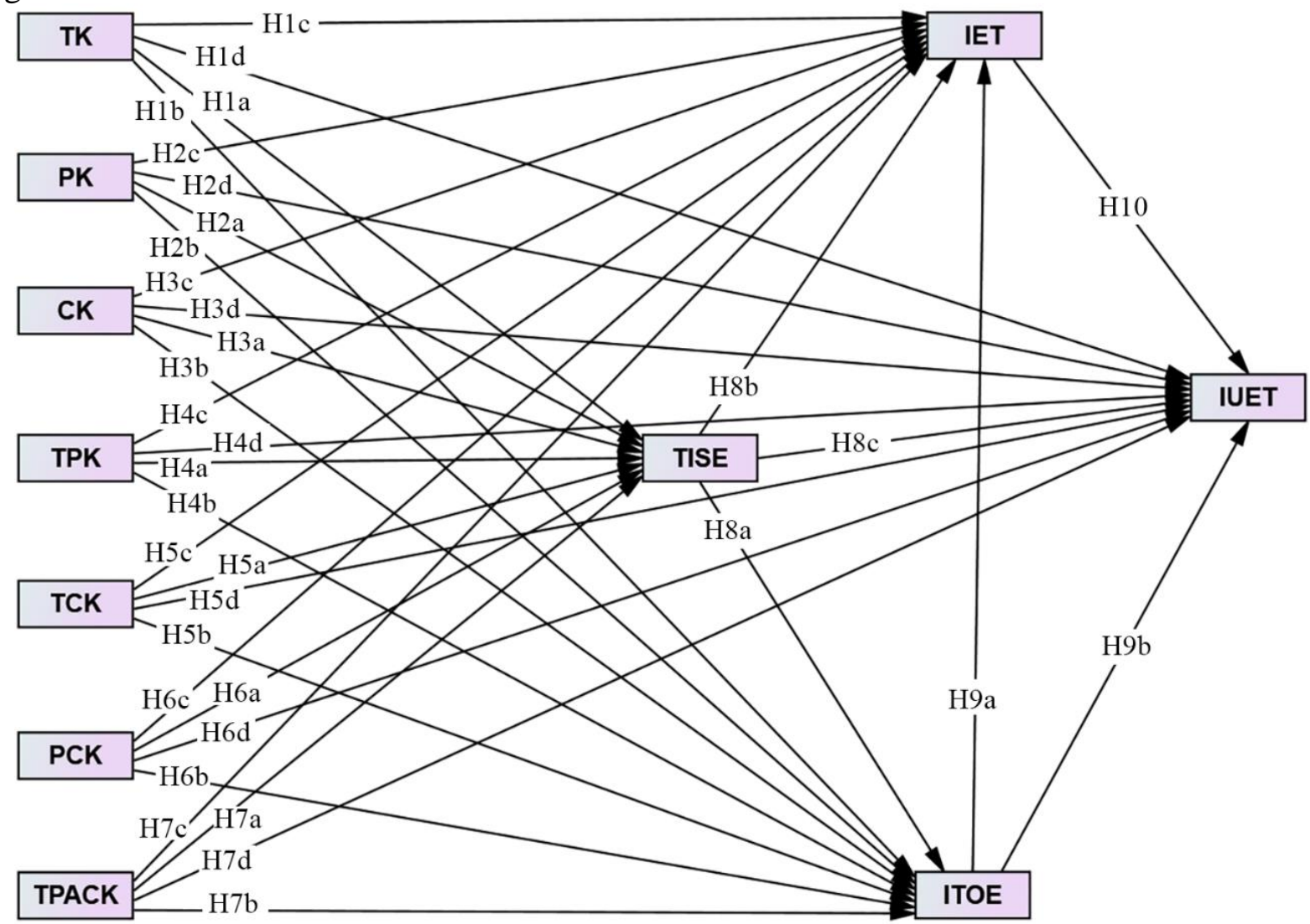

Figure 2. Hypothetical model for explaining teachers' behaviors in technology integration 
H1a-b-c-d. TK positively influences TISE, ITOE, IET, and IUET.

$\mathrm{H} 2 \mathrm{a}-\mathrm{b}-\mathrm{c}-\mathrm{d}$. PK positively influences TISE, ITOE, IET, and IUET.

H3a-b-c-d. CK positively influences TISE, ITOE, IET, and IUET.

H4a-b-c-d. TPK positively influences TISE, ITOE, IET, and IUET.

H5a-b-c-d. TCK positively influences TISE, ITOE, IET, and IUET.

H6a-b-c-d. PCK positively influences TISE, ITOE, IET, and IUET.

H7a-b-c-d. TPACK-core positively influences TISE, ITOE, IET, and IUET.

H8a-b-c. TISE positively influences ITOE, IET, and IUET.

H9a-b. ITOE positively influences IET and IUET.

H10. IET positively influences IUET.

\section{Method}

\section{Participants}

The convenience sampling technique was used in this study to obtain participants. The participants were teachers working at primary, secondary, and high schools in four different cities (Afyonkarahisar, Burdur, Denizli, and Isparta) in the Lakes Region of Turkey. Necessary permissions were obtained from the Ministry of National Education (MoNE) in order to apply the questionnaire form to the teachers. The researcher visited schools and explained the purpose of the research to collect the data of the study in the spring semester of 2014-2015 academic year. In order to achieve greater statistical power in the study, 1000 teachers were asked to participate in the research, and 944 of them responded voluntarily. It was approximately 15 minutes to complete the questionnaire. The data of 850 teachers were involved in the study after excluding incorrect or missing data and univariate and multivariate outliers. The ages of the participants ranged from 21 to 62 (Mean=37.9, $\mathrm{SD}=8.73$ ). Demographic statistics concerning teachers' gender, educational status, and school are given in Table 1.

Table 1. Demographic variables

\begin{tabular}{llll}
\hline & & Frequency $(f)$ & Percentage $(\%)$ \\
\hline Gender & Female & 337 & 39.6 \\
\multirow{3}{*}{ Educational Status } & Male & 513 & 60.4 \\
& Undergraduate & 727 & 85.5 \\
\multirow{3}{*}{ School } & Graduate & 123 & 14.5 \\
& Primary & 211 & 24.8 \\
& Secondary & 275 & 32.4 \\
& High School & 364 & 42.8 \\
& Total & 850 & 100 \\
\hline
\end{tabular}

In the study, the participants were asked about their conditions related to the technological infrastructure of their schools, in-service training on ICT, technology ownership, and the use of ICT in their courses. The results are shown in Table 2. 
Table 2. Teachers' access and use of technologies

\begin{tabular}{ccc}
\hline & Frequency $(f)$ & Percentage $(\%)$ \\
\hline Technological infrastructure of the school & & \\
Sufficient & 475 & 55.9 \\
Insufficient & 375 & 44.1 \\
In-service training on ICT & 526 & \\
Yes & 324 & 61.9 \\
No & & 38.1 \\
Technology ownership & 471 & \\
Desktop PC & 711 & 55.4 \\
Laptop & 398 & 83.6 \\
Tablet & 636 & 46.8 \\
Smart phone & & 74.8 \\
Never & 45 & \\
Rarely & 107 & 5.3 \\
Sometimes & 239 & 12.6 \\
Often & 238 & 28.1 \\
Always & 221 & 28.0 \\
\hline
\end{tabular}

\section{Data collection instruments}

\section{Technological pedagogical content knowledge scale}

The scale developed by Sahin (2011) was used to measure teachers' technological pedagogical content knowledge. This scale consists of a total of seven dimensions and 47 items including TK (15 items), PK (six items), CK (six items), TPK (four items), TCK (four items), PCK (seven items), and TPACK-core (five items). The scale is a Likert-type with five options ( $1=$ not at all, $2=$ little, $3=$ moderate, $4=$ quite, and $5=$ complete). Some sample items of the TPACK survey are shown in Table 3.

Table 3. Sample items of TPACK survey

\begin{tabular}{ll}
\hline Subscale & Sample items (I have knowledge in ...) \\
\hline TK & - Using a presentation program (ex., MS Powerpoint) \\
PK & - Using digital camera \\
& - Eliminating individual differences \\
CK & - Managing class \\
& - Knowing about key subjects in my area \\
TPK & - Following recent developments and applications in my content area \\
& - Choosing technologies appropriate for my teaching/learning approaches and strategies \\
PCK & - Evaluating appropriateness of a new technology for teaching and learning \\
& - Selecting appropriate and effective teaching strategies for my content area \\
TCK & - Preparing a lesson plan including class/school-wide activities \\
& - Using area-specific computer applications \\
TPACK- & - Preparing a lesson plan requiring use of instructional technologies \\
core & - Integrating appropriate instructional methods and technologies into my content area \\
\hline
\end{tabular}

Higher scores taken in each of the sub-dimensions show that the participant has a better perspective regarding the practice of relevant knowledge. Cronbach's alpha internal consistency coefficients of TK, PK, CK, TPK, TCK, PCK, and TPACK-core dimensions were calculated respectively $0.95,0.91,0.89,0.90,0.91,0.94$, and 0.91 . Because each dimension was defined as a variable, a separate confirmatory factor analysis was conducted for each dimension to confirm their construct validities. Based on the results, the variables of TK (RMSEA=0.06, SRMR=0.03, GFI=0.96, CFI=0.98, TLI=0.97), PK (RMSEA=0.00, 
$\mathrm{SRMR}=0.01, \mathrm{GFI}=1.00, \mathrm{CFI}=1.00, \mathrm{TLI}=1.00), \mathrm{CK}(\mathrm{RMSEA}=0.05, \mathrm{SRMR}=0.01, \mathrm{GFI}=0.99$, $\mathrm{CFI}=1.00$, TLI=0.99), TPK (RMSEA=0.05, SRMR=0.01, GFI=1.00, CFI=1.00, TLI=0.99), TCK (RMSEA=0.00, SRMR=0.00, GFI=1.00, CFI=1.00, TLI=1.00), PCK (RMSEA=0.04, SRMR $=0.01, \quad \mathrm{GFI}=0.99, \quad \mathrm{CFI}=1.00, \quad \mathrm{TLI}=0.99$ ), and TPACK-core (RMSEA $=0.05$, $\mathrm{SRMR}=0.01, \mathrm{GFI}=1.00, \mathrm{CFI}=1.00, \mathrm{TLI}=0.99)$ were found to have acceptable construct validity.

\section{Instructional technology outcome expectations scale}

The scale developed by Perkmen, Niederhauser, and Charania (2006) adapted to Turkish by Sahin (2008) was used to measure teachers' expectation levels regarding technology integration. It is a Likert-type scale consisting of nine items, such as "Using educational technology in my career will likely allow me to increase my sense of accomplishment", "Using educational technology in my career will likely allow me to teach effectively", and "Using educational technology in my career will likely allow me to increase the quality of my work", each with four options ("strongly disagree" to "strongly agree"). Cronbach's alpha internal consistency coefficient was found to be 0.93 . In addition, the confirmatory factor analysis was done to examine the construct validity of the scale (RMSEA=0.07, SRMR=0.03, GFI=0.98, CFI=0.99, TLI=0.98). The results indicated that this scale had acceptable construct validity.

\section{Technology integration self-efficacy scale}

The scale developed by Wang, Ertmer, and Newby (2004) adapted to Turkish by Sahin (2008) was used to measure teachers' self-efficacy levels in using educational technology regarding technology integration. It is a Likert-type scale consisting of eight items, such as "I feel confident that I can demonstrate necessary skills to use educational technology in the classroom", "I feel confident that I can help students when they have difficulty with educational technology", and "I feel confident that I can use educational technology that will aid in meeting curriculum standards", each with five options ("not confident" to "strongly confident"). Cronbach's alpha internal consistency coefficient was found to be 0.96. In addition, the confirmatory factor analysis was done to examine the construct validity of the scale (RMSEA=0.04, SRMR=0.01, GFI=0.99, CFI=1.00, TLI=1.00). The results showed that this scale had acceptable construct validity.

\section{Interest in educational technologies scale}

The scale developed by Fouad and Smith (1996) adapted to Turkish by Sahin (2008) was used to measure teachers' interest levels related to educational technologies. It is a Likert-type scale consisting of six items, such as "How much interest do you have in reading books or articles about educational technology?", "How much interest do you have in learning about new educational software?", and "How much interest do you have in working on a project involving educational technology concepts?", each with five options ("not interested" to "strongly interested"). Cronbach's alpha internal consistency coefficient was found to be 0.93. Additionally, the confirmatory factor analysis was done to examine the construct validity of the scale (RMSEA=0.05, $\mathrm{SRMR}=0.01, \mathrm{GFI}=0.99, \mathrm{CFI}=1.00, \mathrm{TLI}=0.99$ ). The results demonstrated that this scale had acceptable construct validity. 


\section{Intentions to use educational technologies scale}

The scale developed by Sahin (2008) was used to measure teachers' intentions levels in using educational technologies. It is a Likert-type scale consisting of four items, such as "I intend to gain more skills on educational technology", "I intend to prepare classroom activities and student projects involving educational technology", and "I intend to attend to training programs on educational technology", each with five options ("strongly disagree" to "strongly agree"). Cronbach's alpha internal consistency coefficient was found to be 0.87 . Additionally, the confirmatory factor analysis was done to examine the construct validity of the scale (RMSEA=0.05, SRMR=0.01, CFI=1.00, TLI=0.99). The results indicated that this scale had acceptable construct validity.

\section{Data verification}

Descriptive statistics such as frequencies, percentages, and means were used in the study. Furthermore, a correlation analysis was conducted to determine the relationships between variables. Lastly, the model was tested by structural equation modeling (SEM), and path analysis was done in order to identify the significance of the model and to show the direct and indirect effects of variables. SEM is a sophisticated method to show relationships among observed variables or quantitatively test a structural model hypothesized by the researcher (Schumacker \& Lomax, 2012). The data were analyzed with IBM SPSS Amos 19.

Before data analysis, the assumptions were checked. Standard z-score values were calculated to ensure normality by removing univariate outliers, and therefore the values outside of the \pm 3 were removed. The skewness and kurtosis coefficients of variables were observed between \pm 1 , and the univariate normal distribution assumption was met (George \& Mallery, 2003). For multivariate normality assumption, Mahalanobis distance values were examined, and those that were higher than the critical value were identified as multivariate outliers, and they were not involved in the analysis. Also, the multivariate normality and linearity of each variable were assured via scatterplot matrix (Kline, 2005; Tabachnick \& Fidell, 2007).

In order to test the assumption of multicollinearity, Pearson correlation coefficients between variables, the variance inflation factor (VIF) and tolerance values (TV) were calculated. The correlation values between variables were not higher than 0.90. The VIF values ranging from 1.48 to 4.95 are below the suggested value of 10 , and tolerance values (TV) ranging from 0.20 and 0.67 are above the suggested value of 0.10 . Therefore, the assumption of multicollinearity was met.

In the SEM literature, the sample size of less than 100 is unacceptable, between 100 and 200 is moderately acceptable, and more than 200 is acceptable for SEM analysis (Bentler \& Chou, 1987; Jayaram, Kannan, \& Tan, 2004; Kline, 2005). After removing univariate and multivariate outliers, the number of participants involved in the analysis was 850 teachers. In this context, the sample size required for the SEM analysis was met. 


\section{Results}

The descriptive statistics and the relationships between the variables are shown in Table 4.

Table 4. Descriptive statistics

\begin{tabular}{|c|c|c|c|c|c|c|c|c|c|c|c|c|c|c|}
\hline Variables & Range & Mean & SD & 1 & 2 & 3 & 4 & 5 & 6 & 7 & 8 & 9 & 10 & 11 \\
\hline 1. TK & $21-75$ & 53.21 & 12.01 & - & & & & & & & & & & \\
\hline 2. PK & $12-30$ & 23.18 & 3.84 & $0.54 *$ & - & & & & & & & & & \\
\hline 3. CK & $12-30$ & 23.40 & 3.82 & $0.44 *$ & $0.71 *$ & - & & & & & & & & \\
\hline 4. TPK & $8-20$ & 15.52 & 2.64 & $0.65^{*}$ & $0.74 *$ & $0.73 *$ & - & & & & & & & \\
\hline 5. TCK & $7-20$ & 15.03 & 2.89 & $0.67 *$ & $0.70^{*}$ & $0.67 *$ & $0.85^{*}$ & - & & & & & & \\
\hline 6. PCK & $14-35$ & 27.56 & 4.50 & $0.51 *$ & $0.75 *$ & $0.70 *$ & $0.76^{*}$ & $0.77 *$ & - & & & & & \\
\hline 7. TPACK & $9-25$ & 19.27 & 3.36 & $0.59 *$ & $0.72 *$ & $0.69 *$ & $0.79 *$ & $0.80^{*}$ & $0.84 *$ & - & & & & \\
\hline 8. TISE & $12-40$ & 28.87 & 6.37 & $0.66^{*}$ & $0.55^{*}$ & $0.51 *$ & $0.67 *$ & $0.69 *$ & $0.59 *$ & $0.67 *$ & - & & & \\
\hline 9. ITOE & $20-45$ & 37.58 & 5.60 & $0.35^{*}$ & $0.34 *$ & $0.35 *$ & $0.43 *$ & $0.44 *$ & $0.42 *$ & $0.48 *$ & $0.53 *$ & - & & \\
\hline 10. IET & $6-30$ & 19.21 & 5.16 & $0.58^{*}$ & $0.41 *$ & $0.41 *$ & $0.52 *$ & $0.53^{*}$ & $0.44 *$ & $0.53 *$ & $0.68 *$ & $0.44 *$ & - & \\
\hline 11. IUET & $9-20$ & 16.20 & 2.40 & $0.40 *$ & $0.38 *$ & $0.38 *$ & $0.44 *$ & $0.44 *$ & $0.42 *$ & $0.49 *$ & $0.54 *$ & $0.53 *$ & $0.62 *$ & - \\
\hline
\end{tabular}

$* \mathrm{p}<0.01$

In Table 4, considering range scores, teachers' TK, PK, CK, TPK, TCK, PCK TPACK-core, TISE, ITOE, IET, and IUET mean scores are above the midpoint of their respective scales. These results indicate that teachers had sufficient knowledge and skills in terms of technology integration, although nearly half of the teachers (see in Table 2) do not frequently use ICT in their courses because of insufficient technological infrastructure in their schools. Additionally, it was found that there are positive and significant relationships at a moderate or strong level between the variables $(\mathrm{p}<0.01)$.

As a result of the first path analysis, the paths between PK, CK, PCK and TISE, ITOE, IET, and IUET were not statistically significant $(\mathrm{p}>0.05)$. The paths between TK and ITOE and IUET; TPK and ITOE, IET and IUET; TCK and ITOE, IET and IUET; and TPACK-core and IET variables were also not statistically significant. In addition, the path between TISE and IUET was non-significant ( $\mathrm{p}>0.05$ ). These findings suggest that PK, CK, and PCK have no effect on TISE, ITOE, and IUET. Moreover, the finding that there were non-significant paths between TK and ITOE and IUET; TPK and ITOE, IET, IUET; TCK and ITOE, IET and IUET, TPACK-core and IET, and TISE and IUET demonstrates that although these variables have indirect effects on the above-mentioned variables, they have no direct effect on them. The final version of the model was created by removing the non-significant paths. The result of the final path analysis is shown in Figure 3. 


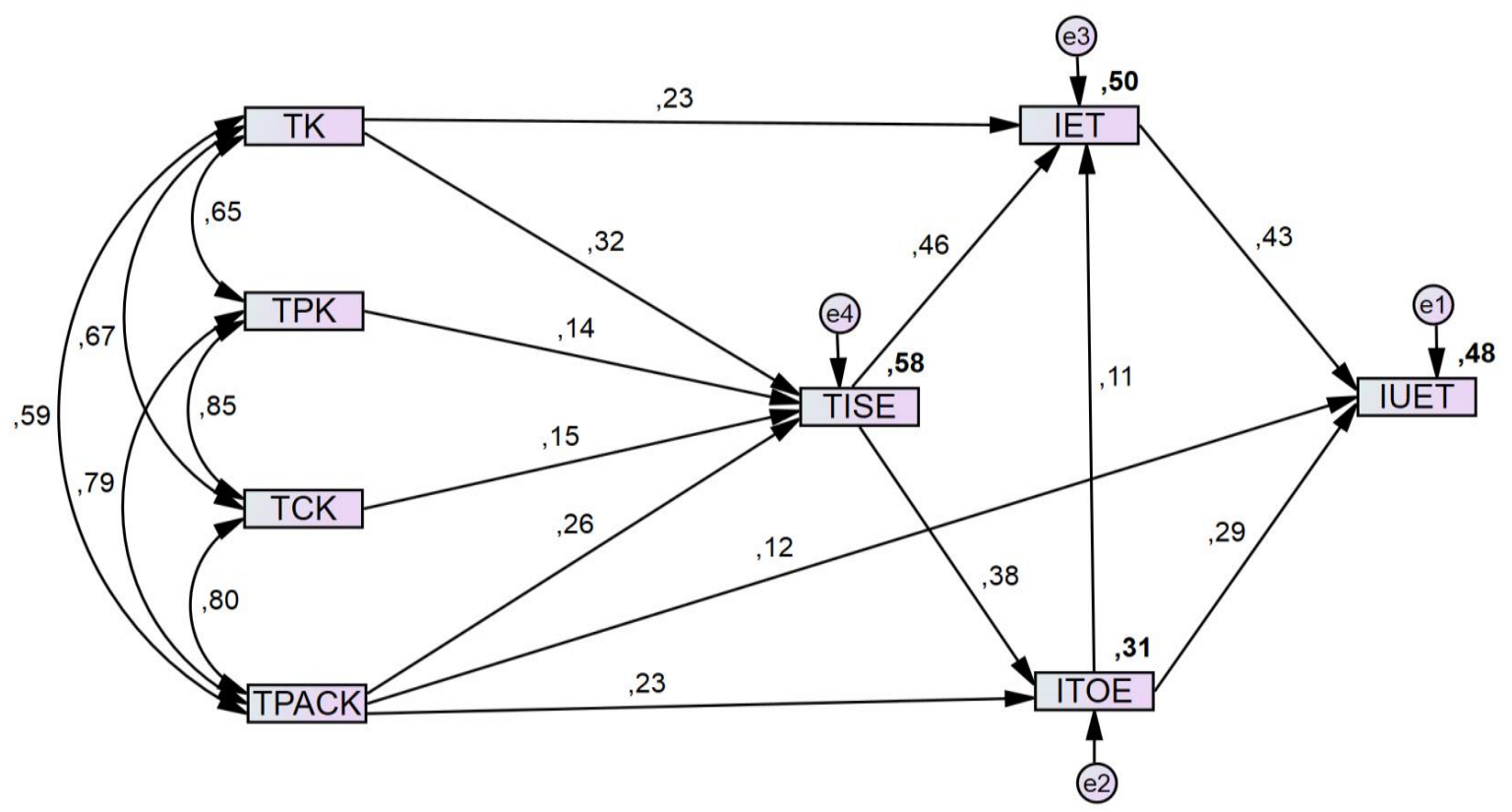

Figure 3. The path diagram of the structural model

After removing the non-significant paths, the Chi-square $(\chi 2=9.30, p=0.50)$ value of the model was found to be statistically not significant. This result demonstrates that the model is fit (Kline, 2005). Because of the possibility that the Chi-square statistic can be affected by sample size, the ratio of the Chi-square value to the degree of freedom $\left(\chi^{2} / \mathrm{df}\right)$ was also checked. As the $\chi^{2}$ df value was found as 0.93 , the model is in good fit according to Kline (2005) $(\chi 2 / \mathrm{df}<3)$. Given the other fit indices of the improved structural model (RMSEA= $0.00, \mathrm{SRMR}=0.01, \mathrm{GFI}=1, \mathrm{CFI}=1, \mathrm{TLI}=1, \mathrm{NFI}=1, \mathrm{AGFI}=0.99$ ), the model can be described as acceptable and in good fit. When the total variance amounts explained on the internal variables are considered, this value appears as $58 \%$ on TISE, $50 \%$ on IET, $31 \%$ on ITOE, and $41 \%$ on IUET. The direct and indirect effects of the variables in the structural model are shown in Table 5.

Table 5. Direct, indirect, and total effect sizes among the variables

\begin{tabular}{|c|c|c|c|c|c|c|c|c|}
\hline & & TK & TPK & TCK & TPACK-core & IET & TISE & ITOE \\
\hline \multirow[t]{4}{*}{ Direct Effect } & IET & 0.23 & 0.00 & 0.00 & 0.00 & 0.00 & 0.46 & 0.11 \\
\hline & TISE & 0.32 & 0.14 & 0.15 & 0.26 & 0.00 & 0.00 & 0.00 \\
\hline & ITOE & 0.00 & 0.00 & 0.00 & 0.23 & 0.00 & 0.38 & 0.00 \\
\hline & IUET & 0.00 & 0.00 & 0.00 & 0.12 & 0.43 & 0.00 & 0.29 \\
\hline \multirow[t]{4}{*}{ Indirect Effect } & IET & 0.16 & 0.07 & 0.07 & 0.16 & 0.00 & 0.04 & 0.00 \\
\hline & TISE & 0.00 & 0.00 & 0.00 & 0.00 & 0.00 & 0.00 & 0.00 \\
\hline & ITOE & 0.12 & 0.05 & 0.06 & 0.10 & 0.00 & 0.00 & 0.00 \\
\hline & IUET & 0.21 & 0.05 & 0.05 & 0.16 & 0.00 & 0.33 & 0.05 \\
\hline \multirow[t]{4}{*}{ Total Effect ${ }^{\mathrm{a}}$} & IET & 0.39 & 0.07 & 0.07 & 0.16 & 0.00 & 0.50 & 0.11 \\
\hline & TISE & 0.32 & 0.14 & 0.15 & 0.26 & 0.00 & 0.00 & 0.00 \\
\hline & ITOE & 0.12 & 0.05 & 0.06 & 0.33 & 0.00 & 0.38 & 0.00 \\
\hline & IUET & 0.21 & 0.05 & 0.05 & 0.28 & 0.43 & 0.33 & 0.34 \\
\hline
\end{tabular}

${ }^{\text {a. }}$ Total Effect $=$ Direct Effect + Indirect Effect

When the direct, indirect, and total effects on the model are examined together, it can be inferred that IET and ITOE are significant in that they both directly affect IUET and mediate TK, TPK, TCK, TPACK-core, TISE, and ITOE to affect IUET. In addition, it was found that 
teachers' TPACK-core, ITOE, and IET have a direct effect on their intentions to use educational technologies.

\section{Discussion}

In this study, a hypothesized structural model was designed to explain the relationships between teachers' TPACK dimensions, technology integration self-efficacy, instructional technology outcome expectations, interest in educational technologies, and intentions to use educational technologies, and to understand the structure in their technology integration behaviors. The results of the study showed that teachers' TK, PK, CK, TPK, TCK, PCK, TPACK-core, TISE, ITOE, IET, and IUET mean scores were above the midpoint of their respective scales. In addition, teachers' TPACK dimensions were positively related to their technology integration self-efficacy, instructional technology outcome expectations, interest in educational technologies, and lastly intentions to use educational technologies. Since intentions give rise to successful behaviors (Lent et al., 2002; Sahin, 2008), if teachers have sufficient technological infrastructure in their schools, they can effectively use technology in education and shows technology integration behaviors. There are studies supporting this finding in the relevant literature (Abbitt, 2011; Karatas, 2014; Nathan, 2009; Semiz \& Ince, 2012). However, as a result of testing our research hypotheses, teachers' pedagogical knowledge, content knowledge, and pedagogical content knowledge separately did not significantly affect their technology integration self-efficacy, instructional technology outcome expectations, interest in educational technologies, and intentions to use educational technologies. Similarly, the studies in the literature show that pedagogical knowledge, content knowledge or pedagogical content knowledge have no effect on teachers' technology usage and self-efficacy beliefs with regard to technology integration (Abbitt, 2011; Ozgen, Narli, \& Alkan, 2013). In this context, it is said that teachers' pedagogical knowledge or content knowledge alone cannot make sense in the integration of technology, but it helps to ensure technology integration when blended with technological knowledge.

The study showed that teachers' TK directly affected IET and TISE. Furthermore, we observed that teachers' TK had the most direct effect on TISE, and it had the highest effect on IET. In this context, teachers' technological knowledge influences their intentions to use educational technologies through their self-efficacy, interest, and outcome expectations. Teachers who have higher levels of technological knowledge consider themselves more capable in the use of technology and have positive attitudes about technology integration (Abbitt, 2011; Ozturk, 2013; Tokmak, 2013). Although teachers' technological knowledge helps to explain their interest in educational technologies and technology integration selfefficacy, it may not be enough by itself to explain outcome expectations and their intention to use educational technologies.

Teachers' TPK and TCK had a direct effect on their TISE. Similarly, prior studies show that teachers' TPK and TCK have a significant effect on their technology integration self-efficacy, thus enabling them to perceive themselves as competent with regard to the use of technology in education (Abbitt, 2011; Chieng, \& Tan, 2021; Ozturk, 2013). However, teachers' technological pedagogical knowledge and technological content knowledge had a limited indirect effect on their interest, outcome expectations, and intentions to use educational technologies through their technology integration self-efficacy. At this point, the study also exposed that the core component of technological pedagogical content knowledge (TPACKcore) directly affected teachers' intention to use educational technologies, even though other components (TK, PK, CK, TPK, TCK, and PCK) had no direct effect. Additionally, teachers' TPACK-core identifies their interest in educational technologies with relation to technology 
integration self-efficacy and instructional technology outcome expectations. Similarly, some studies showed strong relationships between TPACK and TISE (e.g., Bakar, Maat, \& Rosli, 2000; Yildiz Durak, 2019), while others found a moderate relationship between TPACK dimensions, TISE, and ITOE (Semiz \& Ince, 2012). Koehler et al. (2014) emphasized that TPACK is necessary for teachers to be informed about effective technology integration. In this context, teachers' TPACK-core is an important factor for effective technology integration and decisions about technology use in education (Sobel \& Grotti, 2013; Spazak, 2013; Uslu, 2018; Tosuntas, Cubukcu, \& Beauchamp, 2021).

The study revealed that teachers' TISE affects their IUET through their IET and ITOE. This result suggests that TISE influences teachers' IUET indirectly, and this finding is similar to Sahin's (2008) study. The literature also shows similar relations between these variables (Antoine, 2011; Baker-Eveleth \& Stone, 2008; Chang \& Tung, 2008; Niederhauser \& Perkmen, 2008; Pauli, Gilson, \& May, 2007). Besides, some studies demonstrate that teachers' technology integration self-efficacies play a key role in the development of their intentions to use educational technologies (Anderson, Groulx, \& Maninger, 2011; Anderson \& Maninger, 2007; Banas \& York, 2014; Spazak, 2013; Teo, 2009). In this regard, teachers' perceptions of their competence about technology integration contribute positively to their ability to manage problems in the technology integration process and their efforts to integrate technology into their classrooms (Ajzen, 1991). Although self-efficacy is a strong and significant predictor of outcome expectations and interest (Sahin, 2008), it is not enough to ensure technology integration on its own. Besides, instructional technology outcome expectations and interest in educational technologies are also important indicators of teachers' intentions to use educational technologies (Niederhauser \& Perkmen, 2008; Sahin, 2008). According to literature, teachers' outcome expectations and interests in educational technologies in the instructional process shape their technology integration behaviors in the classrooms (Stewart, 2012; Tokmak, 2013). In summary, besides TK, TCK, TPK, and TPACK-core, teachers' self-efficacy, outcome expectations, and interests contribute to explaining their intentions to use educational technology. Since intentions increase the possibility of engaging in an action (Lent et al., 2002; Sahin, 2008), especially teachers' TK, TCK, TPK, and TPACK-core (different interactions of CK and PK with TK) together with their self-efficacy, outcome expectations, interest and intentions affect their technology integration behaviors and will likely lead to the successful integration of educational technologies into instructional processes.

\section{Conclusions, limitations and implications}

The main merit of the study is lies in the fact that it brings new evidence and a finer grained understanding of the complex phenomenon of technology integration in schools, rather than finding out something unexpected or completely new. However, the method (SEM) used in the study, allowed to test a structural model combining TPACK dimensions and some social cognitive variables; thus, it provided obtaining a more detailed vision of the relationships between the considered variables. In this way, we can see the causal relationships to understand the structure of teachers' technology integration behaviors from a different perspective.

This study presents some limitations and implications. The sample targeted teachers and collected data in Turkey. This may restrict the generalizability of our findings. Future studies may benefit sampling from a wider or different population. Furthermore, it is necessary to test the model in different samples in order to assure whether or not it is specific to a certain 
group. Also, this structural model can be further developed by adding different variables, such as personal or environmental variables, to reflect other factors that might influence teachers' technology integration behaviors.

Technological knowledge alone should not be regarded as adequate knowledge for teachers' technology integration, and the interactions between TPACK dimensions are important to integrate technology in education effectively. For this purpose, in-service training should be organized and more practical training should be given to teachers in schools, especially those who have relatively less experience in the profession. Also, as Kapici and Akcay (2020) suggested, pre-service teachers should be provided with opportunities to design technologyenhanced curriculum materials for developing their self-efficacy beliefs about technology integration. Considering the relationships between TPACK dimensions and other variables in this study, teacher trainings should also focus on the development of the knowledge and cognitive skills as well as other factors that may affect technology integration in education. In addition, it may be useful to show practical examples and good implementations for effective technology integration that may be a role model for teachers to increase their expectations and interests in using educational technologies.

\section{Acknowledgment}

This study is based on the first author's master's thesis and it was conducted under project number 4347-YL1-15 at the Scientific Research Projects Coordination Unit, Süleyman Demirel University in Turkey.

\section{Statements on open data, ethics and conflict of interest}

For inquiries or admission to the data sets collected during this research, please contact the author via the contact information given at the correspondence section.

Before the study, all necessary permissions were collected from the institutions (university and the Ministry of National Education) where the data was gathered. Also, only volunteer teachers participated in the study and all participants signed a voluntary participation form.

There is no potential conflict of interest in the work.

\section{References}

Abbitt, J. T. (2011). An investigation of the relationship between self-efficacy beliefs about technology integration and technological pedagogical content knowledge (TPACK) among preservice teachers. Journal of Digital Learning in Teacher Education, 27(4), 134-143. http://dx.doi.org/10.1080/21532974.2011.10784670

Ajzen, I. (1991). The theory of planned behavior. Organizational Behavior and Human Decision Processes, 50, 179-211. https://doi.org/10.1016/0749-5978(91)90020-T

Albion, P. R. (2001). Some factors in the development of self-efficacy beliefs for computer use among teacher education students. Journal of Technology and Teacher Education, 9(3), 321-347.

Alemdag, E., Cevikbas, S. G., \& Baran, E. (2020). The design, implementation and evaluation of a professional development programme to support teachers' technology integration in a public education centre. Studies in Continuing Education, 42(2), 213-239.

Anderson, S. E., Groulx, J. G., \& Maninger, R. M. (2011). Relationships among preservice teachers' technology-related abilities, beliefs, and intentions to use technology in their 
future classrooms. Journal of Educational Computing Research, 45(3), 321-338. https://doi.org/10.2190/EC.45.3.d

Anderson, S. E., \& Maninger, R. M. (2007). Preservice teachers' abilities, beliefs, and intentions regarding technology integration. Journal of Educational Computing Research, 37(2), 151-172.

Antoine, M. V. (2011). Sources of computer self-efficacy: the relationship to outcome expectations, computer anxiety, and intention to use computers. Unpublished doctoral thesis, Faculty of the Graduate School Southern University and Agricultural and Mechanical College.

Bakar, N. S. A., Maat, S. M., \& Rosli, R. (2020). Mathematics teacher's self-efficacy of technology integration and technological pedagogical content knowledge. Journal on Mathematics Education, 11(2), 259-276.

Baker-Eveleth, L. \& Stone, R.W. (2008). Expectancy theory and behavioral intentions to use computer applications. Interdisciplinary Journal of Information, Knowledge, and Management, 3, 135-146.

Banas, J. R., \& York, C. S. (2014). Authentic learning exercises as a means to influence preservice teachers' technology integration self-efficacy and intentions to integrate technology. Australasian Journal of Educational Technology, 30(6).

Bandura, A. (1986). Social foundations of thought and action: A social cognitive theory. New Jersey: Prentice-Hall.

Baran, E., Chuang, H. H., \& Thompson, A. (2011). Tpack: An emerging research and development tool for teacher educators. Turkish Online Journal of Educational Technology, 10 (4), 370-377.

Bentler, P. M., \& Chou, C. P. (1987). Practical issues in structural modeling. Sociological Methods \& Research, 16(1), 78-117.

Bong, M., \& Skaalvik, E. M. (2003). Academic self-concept and self-efficacy: How different are they really? Educational Psychology Review, 15, 1-40. https://doi.org/10.1023/A:1021302408382

Carr, A. A., Jonassen, D. H., Litzinger, M. E., \& Marra, R. M. (1998). Good ideas to foment educational revolution: The role of systematic change in advancing situated learning, constructivism, and feminist pedagogy. Educational Technology, 38(1), 5-14.

Chang, S.-C., \& Tung, F. C. (2008). An empirical investigation of students' behavioral intentions to use the online learning course websites. British Journal of Educational Technology, 39(1), 71-83. https://doi.org/10.1111/j.1467-8535.2007.00742.x

Chieng, Y. E., \& Tan, C. K. (2021). A sequential explanatory investigation of TPACK: Malaysian science teachers ${ }^{\text {ee }}$ survey and perspective. International Journal of Information and Education Technology, 11(5).

Compeau, D., \& Higgins, C. (1995). Computer self-efficacy: Development of a measure and initial test. MIS Quarterly, 19(2), 189-211. Doi:10.2307/249688.

Demir, S., \& Bozkurt, A. (2011). Primary mathematics teachers' views about their competencies concerning the integration of technology. Elementary Education Online, $10(3), 850-860$.

Fanni, F. (2014). Confidence in technology use: the development and validation of a technological, pedagogical, and content self-efficacy scale for teachers. Doctoral dissertation, Università della Svizzera italiana.

Fouad, N. A., \& Smith, P. L. (1996). A test of a social cognitive model for middle school students: Math and science. Journal of Counseling Psychology, 43(3), 338-346. http://dx.doi.org/10.1037/0022-0167.43.3.338

George, D., \& Mallery, P. (2003). SPSS for windows step by step: A simple guide and reference. 11.0 update (4th ed.). Boston: Allyn \& Bacon. 
Holden, H., \& Rada, R. (2011). Understanding the influence of perceived usability and technology self-efficacy on teachers' technology acceptance. Journal of Research on Technology in Education, 43(4), 343-367. https://doi.org/10.1080/15391523.2011.10782576

Jayaram, J., Kannan, V. R., \& Tan, K. C. (2004). Influence of initiators on supply chain value creation. International Journal of Production Research, 42(20), 4377-4399. http://dx.doi.org/10.1080/00207540410001716516

Karatas, F. I. (2014). An examination of in-service secondary mathematics teachers' technological pedagogical content knowledge and their technology integration selfefficacy. Master dissertation, Bogazici University.

Karatas, I., Tunc, M. P., Yilmaz, N., \& Karaci, G. (2017). An investigation of technological pedagogical content knowledge, self-confidence, and perception of pre-service middle school mathematics teachers towards instructional technologies. Educational Technology \& Society, 20(3), 122-132.

Kapici, H. O., \& Akcay, H. (2020). Improving student teachers' TPACK self-efficacy through lesson planning practice in the virtual platform. Educational Studies, 1-23.

Kereluik, K., Mishra, P., \& Koehler, M. J. (2011). On learning to subvert signs: literacy, technology and the TPACK framework. The California Reader, 44(2), 12-18.

Kline, R. B. (2005). Principles and practice of structural equation modeling (2nd ed.). New York: The Guilford Press.

Koehler, M. J., \& Mishra, P. (2005). What happens when teachers design educational technology? The development of technological pedagogical content knowledge. $J$. Educational Computing Research, 32(2), 131-152. https://doi.org/10.2190/0EW701WB-BKHL-QDYV

Koehler, M. J., \& Mishra, P. (2009). What is technological pedagogical content knowledge? Contemporary Issues in Technology and Teacher Education, 9(1), 60-70.

Koehler, M. J., Mishra, P., Kereluik, K., Shin, T. S., \& Graham, C. R. (2014). The technological pedagogical content knowledge framework. In Handbook of research on educational communications and technology (pp. 101-111). Springer New York. https://doi.org/10.1007/978-1-4614-3185-5_9

Lent, R. W., Brown, S. D., \& Hackett, G. (1994). Toward a unifying social cognitive theory of career and academic interest, choice, and performance. Journal of vocational behavior, 45(1), 79-122. https://doi.org/10.1006/jvbe.1994.1027

Lent, R. W., Brown, S. D., \& Hackett, G. (2002). Social cognitive career theory. In D. Brown (Ed.), Career choice and development (pp. 255-311). San Francisco, CA: Jossey-Bass.

Lent, R. W., Ireland, G. W., Penn, L. T., Morris, T. R., \& Sappington, R. (2017). Sources of self-efficacy and outcome expectations for career exploration and decision-making: A test of the social cognitive model of career self-management. Journal of Vocational Behavior, 99, 107-117. https://doi.org/10.1016/j.jvb.2017.01.002

Mishra, P., \& Koehler, M. J. (2006). Technological pedagogical content knowledge: A framework for teacher knowledge. Teachers College Record, 108(6), 1017-1054.

Morales, G., Knezek, G., \& Christensen, R. (2011). Self-efficacy ratings of technology proficiency among teachers in Mexico and Texas. Computers in Schools, 25(1-2), 126-144.

Nathan, E. J. (2009). An examination of the relationship between preservice teachers' level of technology integration self-efficacy (TIS) and level of technological pedagogical content knowledge (TPACK). Doctoral dissertation, University of Houston.

Niederhauser, D. S., \& Perkmen, S. (2008). Validation of the intrapersonal technology integration scale: Assessing the influence of intrapersonal factors that influence 
technology integration. Computers in the Schools, 25(1-2), 98-111. http://dx.doi.org/10.1080/07380560802157956

Niess, M. L. (2011). Investigating TPACK: knowledge growth in teaching with technology. Journal of Educational Computing Research, 44, 299-317. https://doi.org/10.2190/EC.44.3.c

Ozgen, K., Narli, S., \& Alkan, H. (2013). An investigation of mathematics teacher trainees' technological pedagogical content knowledge and their perception of the frequency of technology use. Electronic Journal of Social Sciences, 12(44), 31-51.

Ozturk, E. (2013). Sınıf öğretmeni adaylarının teknolojik pedagojik alan bilgilerinin bazı değişkenler açısından değerlendirilmesi [Prospective classroom teachers' technological pedagogical content knowledge assessment in terms of some variables]. Uşak Üniversitesi Sosyal Bilimler Dergisi, 6(2), 223-228.

Pauli, K.P., Gilson, R.L., \& May, D.R. (2007). The mediating effect of computer self-efficacy on computer anxiety and intention to use computers. Review of Business Information Systems Journal, 11 (1), $57-64$.

Paraskeva, F., Bouta, H., \& Papagianni, A. (2008). Individual characteristics and computer self-efficacy in secondary education teachers to integrate technology in educational practice. Computers \& Education, 50, 1084-1091. https://doi.org/10.1016/j.compedu.2006.10.006

Perkmen, S., Niederhauser, D. S., \& Charania, A. (2006). Factors that influence preservice teachers' career goals in instructional technology. Annual meeting of American Educational Research Association (AERA).

Raygan, A., \& Moradkhani, S. (2020). Factors influencing technology integration in an EFL context: investigating EFL teachers' attitudes, TPACK level, and educational climate. Computer Assisted Language Learning, 1-22.

Roussinos, D., \& Jimoyiannis, A. (2019). Examining primary education teachers' perceptions of TPACK and the related educational context factors. Journal of Research on Technology in Education, 51(4), 377-397.

Sahin, I. (2008). From the social-cognitive career theory perspective: A college of education faculty model for explaining their intention to use educational technology. Journal of Educational Computing Research, 38(1), 51-66. https://doi.org/10.2190/EC.38.1.c

Sahin, I. (2011). Development of survey of technological pedagogical and content knowledge (tpack). TOJET: The Turkish Online Journal of Educational Technology, 10(1), 97105.

Saudelli, M. G., \& Ciampa, K. (2016). Exploring the role of TPACK and teacher selfefficacy: An ethnographic case study of three iPad language arts classes. Technology, Pedagogy and Education, 25(2), 227-247.

Semiz, K., \& Ince, M. L. (2012). Pre-service physical education teachers' technological pedagogical content knowledge, technology integration self-efficacy and instructional technology outcome expectations. Australasian Journal of Educational Technology, 28(7), 1248-1265. https://doi.org/10.14742/ajet.800

Shealy, T., Valdes-Vasquez, R., Klotz, L., Potvin, G., Godwin, A., Cribbs, J., \& Hazari, Z. (2015). Career outcome expectations related to sustainability among students intending to major in civil engineering. Journal of Professional Issues in Engineering Education and Practice, 142(1), 04015008. https://doi.org/10.1061/(ASCE)EI.1943$\underline{5541.0000253}$

Shulman, L. S. (1986). Those who understand: Knowledge growth in teaching. Educational Researcher, 15(4), 4-14. 
Shulman, L. S. (1987). Knowledge and teaching: Foundations of the new reform. Harvard Educational Review, 57(1), 1-22. https://doi.org/10.17763/haer.57.1.j463w79r56455411

Schumacker, R. E., \& Lomax, R. G. (2004). A beginner's guide to structural equation modeling. Psychology Press.

Skaalvik, E. M., \& Skaalvik, S. (2017). Motivated for teaching? Associations with school goal structure, teacher self-efficacy, job satisfaction and emotional exhaustion. Teaching and Teacher Education, 67, 152-160. https://doi.org/10.1016/j.tate.2017.06.006

Smith, S. M. (2002). Using the social cognitive model to explain vocational interest in information technology. Information Technology, Learning, and Performance Journal, 20(1), 1-9.

Sobel, K., \& Grotti, M. G. (2013). Using the TPACK framework to facilitate decision making on instructional technologies. Journal of Electronic Resources Librarianship, 25(4), 255-262.

Spazak, L. (2013). Secondary preservice teachers' perception of preparedness to integrate technology. Doctoral dissertation, Indiana University of Pennsylvania.

Stewart, J. (2012). Intrapersonal factors affecting technological pedagogical content knowledge in Oklahoma agricultural education teachers. Master dissertation, Oklahoma State University.

Stewart, J., Antonenko, P. D., Robinson, J. S., \& Mwavita, M. (2013). Intrapersonal factors affecting technological pedagogical content knowledge of agricultural education teachers. Journal of Agricultural Education, 54(3), 157-170.

Sen, S. (2020). Modelling the relations between Turkish chemistry teachers' sense of efficacy and technological pedagogical content knowledge in context. Interactive Learning Environments, 1-14.

Tabachnick, B. G., \& Fidell, L. S. (2007). Using multivariate statistics (5th ed.) Boston: Allyn and Bacon.

Teo, T. (2009). Modelling technology acceptance in education: A study of pre-service teachers. Computers \& Education, 52(2), 302-312. https://doi.org/10.1016/j.compedu.2008.08.006

Tokmak, H. S. (2013). Changing preschool teacher candidates' perceptions about technology integration in a TPACK-based material design course. Education as Change, 17(1), 115-129. http://dx.doi.org/10.1080/16823206.2013.773927

Tosuntas, S. B., Cubukcu, Z., \& Beauchamp, G. (2021). A new model for the factors that affect interactive whiteboard usage of teachers and its effect on performance. Education and Information Technologies, 26(3), 3575-3592.

Uslu, O. (2018). Factors associated with technology integration to improve instructional abilities: A path model. Australian Journal of Teacher Education, 43(4), 31-50.

Yildiz Durak, H. (2019). Modeling of relations between K-12 teachers' TPACK levels and their technology integration self-efficacy, technology literacy levels, attitudes toward technology and usage objectives of social networks. Interactive Learning Environments, 1-27.

Wang, L., Ertmer, P. A., \& Newby, T. J. (2004). Increasing preservice teachers' selfefficacy beliefs for technology integration. Journal of Research on Technology in Education, 36(3), 231-249. http://dx.doi.org/10.1080/15391523.2004.10782414

Watson, G. (2006). Technology professional development: Long-term effects on teacher selfefficacy. Journal of Technology and Teacher Education, 14(1), 151-165. 
Wetzel, K., Foulger, T. S., \& Williams, M.K. (2008). The evolution of the required educational technology course. Journal of Computing in Teacher Education, 25(2), $67-71$. 